\title{
TEACHER UNDERSTANDING IMPLICATIONS ON THE DIFFERENCES OF ELEMENTARY SCHOOL STUDENTS
}

\author{
Amartia Putri ${ }^{1}$, Dede Lipiah ${ }^{2}$, Nurul Hidayati $^{3}$, Ina Magdalena ${ }^{4}$ \\ ${ }^{1,2,3,4}$ Pendidikan Guru Sekolah Dasar, Universitas Muhammadiyah Tangerang, Indonesia
}

\section{Article Info}

Article history:

Received: 03-02-2021

Revised: 04-08-2021

Published: 30-09-2021

\section{Keywords:}

Individual Difference

Learning Style

Learning

\begin{abstract}
Every human being was created by the Creator with all the uniqueness and characteristics or characteristics of each. This is referred to as individual differences (individual differences). Individual differences are differences in abilities and characteristics (cognitive, personality, physical skills, etc.) between students at a certain age level and in each particular group. Through educational practices and activities, we can accommodate the individual differences of students. Likewise, the learning styles between each other are also different. There are visual, auditory, and kinesthetic learning styles. The differences in students have big implications for learning in schools. Therefore, education personnel, especially a teacher, must know and understand the differences in students to design learning with appropriate methods, models, and approaches. If learning is carried out by paying attention to differences in students, then the delivery and acquisition of knowledge can be carried out optimally. Thus, learning objectives can be achieved without having to put pressure on students. In addition, the teacher's understanding of individual differences in students can foster a comfortable feeling for learning at school.
\end{abstract}

This is an open access article under the CC BY-SA license.

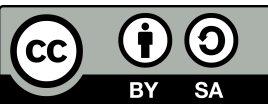

\section{Corresponding Author:}

Amartia Putri,

Pendidikan Guru Sekolah Dasar, Universitas Muhammadiyah Tangerang,

Jl. Perintis Kemerdekaan I/33 Babakan, Tangerang, Indonesia

Email: putriamartia22@gmail.com

\section{INTRODUCTION}

Viewed from a psychological point of view, students can be interpreted as an organism that is growing and developing. They have various human potentials such as talents, interests, social-emotional-personal needs, and physical abilities. These potentials need to be developed through the process of education and teaching, so that others can grow and develop (Milton, 2011). Differences between students can be caused by two main factors, namely congenital and environmental influences. In the world of education, individual differences of students are important things that need to be considered. All forms of policies and implementation of teaching and learning activities in schools must be adapted to the characteristics, talents, abilities, capacities, learning styles, and even the level of intelligence of students. This is in line with the opinion of Hampden-Thompson (2010) which state that students in educational activities are the main object to which everything related to educational activities is referred.

Through the description above, it is clear that individual differences in students are important things that must be known by education implementer, especially teachers as educators because individual differences 
in students have implications for learning carried out in schools. In addition, knowledge of the differences in students is also important to create an attitude of tolerance among students. Teachers can provide examples of acceptance and tolerance so that students feel comfortable in school as well as to instill values and even enjoy differences between them without any suspicion (Kroon et al., 2014).

In essence, each individual is created with all its uniqueness and with their own characteristics. Hereditary factors/heredity or congenital and environmental factors are factors that influence personal/individual differences. These two factors affect the development and growth of students. It is possible that some of these factors are more influential, but both are still influential, and no one is the same between individuals even though they are human beings born with twins (Lutz \& Samir, 2013; Rahman, 2020). The various learning styles will be reviewed, namely (1) Visual learning styles, namely the ability to learn by seeing. (2) Auditory learning style, namely having a better ability in hearing. (3) Kinesthetic learning style, learning by involving the style of motion. Teachers should not equate all their students. To get optimal learning, a teacher must know what students need and try to help meet their learning needs.

\section{RESEARCH METHOD}

The research method used in collecting information is by conducting interviews with teachers at SDN BELENDUNG. The data was obtained through the interview activities. We Amartia Putri, Dede Lipiah and Nurul Hidayati interviewed Mrs. Lia Setyowati, S.Pd on January 19, 2021 at $10.00-12.00$ at SDN BELENDUNG.

\section{RESULT AND DISCUSSION}

\subsection{Result}

Elementary school children have unstable thinking patterns. for example, when a 1st grader in elementary school is asked what he wants to be, the answer is funny, someone wants to be spiderman, and so on, so his mindset is still a child. When asked how the teacher uses this mindset, it is precisely asked for students in junior high and high school. Men's attitude is difficult to manage, while women's attitude is calm. But if you're naughty, you're still naughty (Satriami, Darmiany, \& Saputra, 2021). the handling of teachers for male and female students is different. For example, when a male student makes a mistake, the teacher immediately takes action such as giving advice. Meanwhile, when a female student made a mistake, the teacher immediately approached her and immediately became silent and when her name was called, she was immediately silent, unlike the boys (Berry \& Thunder, 2012).

In the learning process, boys and girls learn differently, for girls the feeling is higher but there are also only a few boys. That's why the teacher when studying RPP in RPP, the learning method is asked to vary because the character of the child is different. When the teacher meets a student who has a calm attitude, the learning method uses a game or game method because the child's attitude is passive, so there must often be games so that everyone is enthusiastic about learning. But when the teacher meets active students, the learning method changes again. The techniques and methods are very influential for student learning. The trick is to wait for time, if the teacher always observes and always supervises, the teacher will definitely know the talents of the students, but for knowledge there is an evaluation as given a question. The methods applied in this school are to apply teaching to students such as: the lecture method, the discussion method, the practice method, the question and answer method and the game or debate method.

\subsection{Discussion}

\subsubsection{Understanding Individual}

In the dictionary of Maja et al. (2021), individual is a noun from individual which means person, individual, and person. Based on the above understanding, an environment for children can be formed that can stimulate the development of their potentials and will bring about any desired changes in their habits and attitudes.

\subsubsection{Individual Characteristics}

Each individual has characteristics and traits or innate characteristics (heredity) and characteristics that are obtained from environmental influences. Innate characteristics are hereditary characteristics that are owned since birth, both concerning biological factors and psychological social factors. Personality, what behavior is 
reinforced, thought about, and felt by a person (individual) is the result of a combination of biological factors as well as innate elements and environmental influences (Nyoman, Astuti, Setiawan, \& Mataram, 2021).

\subsubsection{Individual Differences}

According to Hotimah (2021), Some aspects of individual differences that need attention are differences in intelligence, skills, talent, habit, knowledge, personality, needs, and environmental background.

Sidiq et al. (2020), stated that Individual differences can also come from:

1. Cognitive Differences (intelligence). Cognitive ability is an ability related to the mastery of science and technology. Everyone has a perception of the results of observation or absorption of an object. This means that he controls everything that is known, in the sense that a perception is formed on him, and that knowledge is systematically organized to belong to him.

2. Differences in Language Proficiency. Language is one of the most important individual abilities in life. The ability of each individual in language is different. Language ability is a person's ability to express his thoughts in the form of meaningful, logical and systematic expressions of words and sentences. The ability to speak is strongly influenced by intelligence factors and environmental factors as well as physical factors (speech organs).

3. Differences in Motor Skills. Motor skills or psycho-motor abilities are the ability to coordinate movements of motor requirements carried out by the central nervous system to carry out activities.

4. Background Difference. The different backgrounds and experiences of each of them can facilitate or hinder their achievement, regardless of the individual's potential to master the material and it is what makes them distinguishable.

5. Talent Difference. Talent is a special ability that is brought from birth. This ability will develop well if it gets proper stimulation and fertilization, on the other hand, talent does not develop the same, when the environment does not provide an opportunity to develop, in the sense that there is no stimulation and fertilization that touches it.

6. Differences in Achievement Levels. This is a prominent difference and can be seen from the level of education, in one classroom it is definitely not the same level of achievement as in the exam, they definitely have varying scores, which means they have different achievements.

7. Differences in Family Environment. Children come from various family environments. Children from well-to-do families with adequate education usually come to school with various experience backgrounds and are more likely to become fast learners. On the other hand, children from underprivileged families and with uneducated parents tend to be slow learners.

8. Cultural and Ethnic Background. Children are also different in terms of cultural and ethnic backgrounds. Motivation to learn differs from culture to culture.

9. Educational Factor. Educational factors have a role in distinguishing individuals, for example in one class they study the same subject with the same teacher, but one of them enters or adds to his study schedule at the course, and that can distinguish his knowledge and knowledge.

Factors Affecting Individuals:

1. Congenital Factor

(a) Inherited factors are biological factors that are passed down through genetic inheritance by parents. This genetic inheritance begins at fertilization. According to Haji et al. (2017) the union between a sperm and an egg only produces one in billions of possible combinations of genes. One of the chromosomes, namely the sex chromosomes, is the carrier of the gene code for the development of male or female physical characteristics. The code for us to get an $\mathrm{X}$ chromosome from the mother, and one of the $\mathrm{X}$ or $\mathrm{Y}$ chromosomes from the father. The combination of $\mathrm{XX}$ is the code for the physical development of women, and the combination of $\mathrm{XY}$ is the code for the physical development of men.

(b) Even though we share an average of 50 percent of the same genes as our siblings, our gene pool remains unique unless we are identical twins. This gene difference is one reason why we are different from other people, physically, psychologically, and behaviorally, even from our own siblings. The rest is influenced by the environment, because we have been in the exact same environment (Boger \& Eng, 2010).

2. Environmental Factors

Environmental factors are factors that cause individual differences that come from outside the individual. 
Environmental factors come from several kinds, namely the socioeconomic status of parents, parenting patterns, culture, and birth order.

3. Parents' socioeconomic status

Includes parent's education level, parent's occupation, and parent's income. The level of parents differs from one another. Although this level of education is not absolute, it can influence parents' attitudes towards children's education and their level of aspirations towards children's education. Likewise, with the work and income of different parents. This difference will have implications for the different aspirations of parents for their children's education, their aspirations for their education, the facilities provided to their children and perhaps the time spent educating their children. Likewise, differences in economic status can have implications, one of which is differences in nutritional patterns that are applied in the family.

4. Parenting style

It is a pattern of behavior used to relate to children. The parenting style applied by each family is different from other families. There are three parenting styles in parenting, namely authoritarian, permissive, and authoritative. Authoritarian parenting is a form of parenting that emphasizes parental supervision of children to get obedience or obedience. Parents are strict, punitive, and tend to restrain their children. Permissive parenting is a parenting pattern in which parents give as much freedom as possible to children to regulate themselves, and children are not required to be responsible and not much controlled by parents. While authoritative parenting is a parenting pattern where parents give the same rights and obligations in the sense of complementing each other, children are trained to be responsible, and determine their own behavior in order to be disciplined.

5. Culture

Is a thought, reason, the work of humans, or it can also be defined as customs. The existence of values in society tells its members about what is good and or important in society. These values are described in a norm. The norms of each society are different, so the behavior that emerges from the members of each society is different from one another.

6. Birth order

Although it is still controversial, a person's personality characteristics are influenced by birth order. Firstborns or firstborns tend to be more conscientious, ambitious, and aggressive than their younger siblings. The middle child is often a mediator and a lover of peace. The youngest children tend to be the most creative and usually interesting. The only child or the only child usually often feels burdened by the high expectations of their parents for themselves. They are more confident, outgoing, and have a high imagination. Different characteristics in individuals are influenced by the behavior of their parents based on birth order.

Many educational programs can be chosen by teachers as an implication of the existence of individual differences among students, especially differences in ability. Of the many forms of educational programs that can be chosen, there are 3 types of educational programs that can be implemented, namely: The remedial program is the provision of educational services to students who experience difficulties or obstacles by providing additional lessons and assignments individually so that they can complete the program in accordance with the allotted time and achieve optimal learning outcomes. The enrichment program is the provision of educational services according to the potential for intelligence and additional learning facilities that are in-depth after completing the tasks programmed for other students. The acceleration program is the provision of educational services according to the potential intelligence and special talents possessed by students.

Individual variations that occur in learning at school, although it is a natural thing as a result of the different conditions of individual students, however, should not be allowed by the teacher. Teachers must try to overcome the conditions of individual variation in the student learning process, because if left unchecked, it is certain that there will be striking differences in learning outcomes between students, which as a result the teacher is also considered unsuccessful in teaching, because the average achievement of student learning outcomes is low. Therefore, to overcome individual variations in learning in schools based on the classical teaching system, it must first be overcome by organizing an individual teaching system, namely a way of carrying out teaching that seeks to pay attention to or serve each individual student according to the level of his ability. 


\section{CONCLUSION}

From the results of our interviews, it can be concluded that teachers play an important role for students because teachers have various methods for student learning. So that it makes students understand and also understand the material presented by the teacher because the delivery uses a method that is in accordance with the nature and attitude of the student.

Each individual has characteristics and traits or innate characteristics (heredity) and characteristics that are obtained from environmental influences. Innate characteristics are hereditary characteristics that are owned since birth, both concerning biological factors and social psychological factors. Individual differences, including cognitive differences, language skills differences, motor skills differences, background differences, talents differences, learning readiness differences, achievement levels differences, family environment differences, and cultural backgrounds.

\section{ACKNOWLEDGEMENT}

The author would like to thank all those who have supported the making of this paper with the theme of teachers' understanding of the differences in students in elementary schools.

\section{REFERENCES}

Berry, R., \& Thunder, K. (2012). Mathematics Education at Teachers College. Journal of Mathematics Education at Teachers College, 3(1), 43-55.

Boger, T. S., \& Eng, A.-L. (2010). Student perspective on plagiarism. Nordic Journal of Information Literacy in Higher Education, 3(1 SE - Conference proceedings). doi:10.15845/noril.v3i1.130

Haji, S., Abdullah, M. I., Maizora, S., \& Yumiati, Y. (2017). DEVELOPING STUDENTS' ABILITY OF MATHEMATICAL CONNECTION THROUGH USING OUTDOOR MATHEMATICS LEARNING. Infinity Journal, 6(1), 11. doi:10.22460/infinity.v6i1.234

Hampden-Thompson, G. (2010). Introduction to education studies. Evaluation \& Research in Education. doi:10. 1080/09500791003637923

Hotimah, H., Ermiana, I., \& Rosyidah, A. N. K. (2021). Pengembangan Multimedia Interaktif Berbasis Macromedia Flash Untuk Meningkatkan Kemampuan Komunikasi Matematis. Progres Pendidikan, 2(1), 7-12. doi:10.29303/prospek.v2i1.57

Kroon, F. P., van der Burg, L. R., Buchbinder, R., Osborne, R. H., Johnston, R. V., \& Pitt, V. (2014). Selfmanagement education programmes for osteoarthritis. doi:10.1002/14651858.CD008963.pub2

Lutz, W., \& Samir, K. (2013). Demography and Human Development : Education and Population Projections. United NationsDevelopment Programme.

Maja, C. M. A., Nurhasanah, \& Husniati. (2021). PENGARUH METODE GROUP INVESTIGATION TERHADAP AKTIVITAS BELAJAR MUATAN IPS SISWA KELAS IV SDN 3 SAMBELIA TAHUN THE INFLUENCE OF GROUP INVESTIGATION METHODS ON THE LEARNING ACTIVITIES OF CLASS IV STUDENTS OF SDN 3 SAMBELIA IN THE ACADEMIC YEAR 2020 / 2021. Renjana Pendiidkan Dasar, 1(1), 16-22.

Milton, P. M. (2011). Educational leadership and school culture: A study of the perceptions of ef-fective leadership (Doctoral dissertation).

Nyoman, N., Astuti, S., Setiawan, H., \& Mataram, U. (2021). Pengaruh Model Concept Sentence Berbantuan Flash Card Correlation of Teacher Personality Competence With Discipline of Student Learning in Grade 5 At Sd Negeri Gugus I Lopok Academic Year 2020 / 2021. Renjana Pendidikan Dasar, 1(1), 35-43.

Rahman, I. K. (2020). The Development of E-Counseling Gestalt Prophetic to Help Students Cope with Academic Procrastination in Indonesian Islamic Higher Education. Islamic Guidance and Counseling Journal, 3(1), 46-53. doi:10.25217/igcj.v3i1.614

Satriami, W., Darmiany, \& Saputra, H. H. (2021). Hubungan Kompetensi Kepribadian Guru Dengan Disiplin Belajar Siswa Kelas V Sd Negeri Gugus I Lopok Kota Sumbawa Correlation of Teacher Personality Competence With Discipline of Student Learning in Grade 5 At Sd Negeri Gugus I Lopok Academic Year 2020 / 20. Renjana Pendidikan Dasar, 1(1), 30-34.

Sidiq, D. A. N., Fakhriyah, F., \& Masfuah, S. (2020). Partisipasi Guru Pelaksanaan Bimbingan dan Konseling di SD Kota Mataram NTB. Progres Pendidikan, 1(2), 99-105. 